scientific principle shown in their treatment. It was high time that someone in a position of authority should have been called on to lay down the principles that govern, or should govern, the pruning of trees in public thoroughfares. The outcry periodically made in the daily Press is usually marked by want of knowledge and unfairness. As a matter of fact, there is no work more thankless in nature than the management of street trees. In London and other great urban areas the planter's choice is restricted to a few species (of which the plane is the chief and best) which experience has proved will thrive, but which, as regards size, are quite unsuited to the spaces usually available for them. In the Mall this difficulty does not arise, for the space is ample. The object there is to control the growth of the trees that have been planted so that the foundations of a stately avenue may be laid.

Perhaps the most valuable portion of Prof. Balfour's report is that in which he shows that nature herself is always pruning. That is an aspect of the case which never strikes the lay critic. Yet the smothering out of weakly and overcrowded growths is continually going on. Correct pruning anticipates nature's end, and substitutes the prompt action of the knife for that of slow decay. If one compares the branch-system of a fully grown plane with that of a young specimen, and notes how few of the numerous branches of the latter survive, we see how drastic nature's pruning is. In such a place as the Mall it is essential that the trees should possess a certain uniformity and balanced proportions. The means to secure this end have been admirably chosen, and there the matter may be allowed to remain. But we may recommend Prof. Balfour's report to those who desire to gain some insight into the fundamental laws of tree growth with which the pruner's art should be in unison.

\section{AN EXHIBITION OF BIBLICAL NATURAL HISTORY.}

$A \mathrm{~S}$ a supplement to the literary and historical Biblical exhibition which has been arranged at Bloomsbury for the tercentenary of the Authorised Version, an exhibition of the animals, plants, and minerals mentioned in the Bible has been arranged in one of the bays of the Central Hall of the Natural History Museum, South Kensington. The animals and minerals, respectively, have been selected, arranged, and labelled by Mr. R. Lydekker, F.R.S., and Dr. G. F. Herbert Smith, under the general supervision of the keepers of zoology and mineralogy; the plants have been dealt with by Dr. A. B. Rendle, F.R.S., the keeper of botany. The interesting guide-book to the collection is in great part a reprint of the exhibited labels, which were mainly based on the careful work of the late Canon Tristram. The minerals, which Tristram did not consider, are dealt with in a scholarly essay by the director, Dr. L. Fletcher, F.R.S., who explains how modern interpretations of the ancient names of Biblical minerals have been deduced.

The collection, and the guide to it, will be of special interest to those to whom Bible plants and animals are rich in picturesque associations; but it is, of course, part of a liberal education to know that the " unicorn", was probably the extinct wild ox or aurochs," " behemoth" the hippopotamus, the "coney" the hyrax, and the "leviathan" of Job the crocodile. Some of the corrections are curious; thus the "ferret" of Lev. xi. 30 was probably a gecko, and the "mole" of the same verse a chamæleon, and the "chamæleon" of the same verse a monitor, and the "spider in king's palaces" a gecko. An up-to-date suggestion is noticed, though not acceptedthat the "badger" of Exod. xxvi. I4 was the okapi. We do not see any reference to the "fiery serpent," though the museum used to have a specimen of Filaria medinensis, the guinea-worm, with a label indicating that it was probably that reptile.

What must strike the reader most, especially perhaps when he comes to the botanical part, is the large proportion of misses that the translators made. And if we might venture on a criticism of a carefully executed piece of work, we would suggest that a little more might have been said in explanation of this. A NO 2 I82. VOL. 87 ] paragraph or two on the backward state of natural history when the authorised translation was made three centuries ago would have been interesting. We also wonder why our leading scientific institution has not used this opportunity, which is undoubtedly one of wide popular interest, to tell us-who could do it better?-what is scientifically interesting in the fauna and flora of Palestine.

\section{LIEBIG AND HIS INFLUENCE ON THE PRO GRESS OF MODERN CHEMISTRY.}

A HUNDRED years ago Europe was still plunged in the misery of war. Almost every country had suffered the bitter experience of seeing the devastation caused by the passage of contending armies, the death and suffering of thousands of fighting men, and the want and desolation spread over still greater numbers of a helpless population. Amid all the wretchedness of the time, insecurity of property, dearness of food, frequent changes of governments, and every condition which would appear to be unfavourable, the study of nature steadily went on. France, still staggering from the fierce shocks of the revolutionary period, had still many distinguished men of science, Laplace, Berthollet, Lamarck, Cuvier, while the memory of Lavoisier was fresh and green, and Gay-Lussac, Dulong, Arago, and Chevreul were among the coming men. England, still engaged in the struggle with Napoleon, possessed Humphry Davy, Rumford, and Dalton, and Herschel among the astronomers. Henry Cavendish was still living, though an old man, and Priestley was but lately dead. In Germany, Goethe might be counted among the votaries of science, and Prussia had sent forth Humboldt to survey the world, while in Italy, Volta was busy in the study of electricity, and Avogadro, little noticed by the world, was meditating on the properties of gases and preparing for the enunciation of the great principle which is now associated with his name, though it took the chemical world half a century to recognise it. One other name must not be forgotten, and that is Berzelius, the Swede, then young, and preparing, by his eager activity in research, for that great position of almost undisputed authority in the chemical world, which he filled for nearly forty years.

To understand the influence which any one man appears to have had in his day and generation, it is necessary to bear in mind the condition of the world into which he was born, as well as the quality of his genius. The one reacts on the other. In endeavouring, therefore, to estimate the nature and extent of the services rendered to science, and to the world in general by Liebig, it is necessary to get a clear view of the state of knowledge in chemistry at the time when he appeared on the scene.

Born in Darmstadt, on May 12, 1803 , where his father was a colour manufacturer, he passed through an unsuccessful school career at the local gymnasium, and, at the age of sixteen, was apprenticed to an apothecary. It soon became evident, however, that he was as little fitted to become a pill-maker as he was to be a Greek scholar, and he ultimately persuaded his father to allow him to go to the then newly-founded University of Bonn, whence he followed Kastner, the professor of chemistry, to Erlangen. But Liebig soon became convinced that he could not study chemistry effectively in Germany, and after taking his degree at Erlangen, at the age of nineteen, he proceeded to Paris. There, after many difficulties, he ultimately obtained the privilege of working in Gay-Lussac's laboratory, where he remained about two years. In 1824 , on the recommendation of Humboldt, he was appointed extraordinary professor of chemistry at Giessen, being then only twenty-one years of age. He became ordinary professor two years later, and remained at Giessen until called to Munich, in $185^{2}$. There he died on April 18, 1873 .

Such was the main course of Liebig's career; but to draw a picture of the man from descriptions of his personal characteristics is not easy. In early youth he became familiar with the poet Platen, who noted in his diary "the friendly earnestness in his regular features, great brown eyes, with dark shady eyebrows, which attracted one instantly."

Those brown eyes, shining with earnestness, remain in the portraits which have come down to us, and as a 1 Lecture delivered at Oxford on August 23, at the Fifteenth Summer Meeting, by Sir William A. Tilden, F.R.S. 